\title{
Pregnancy, Incantations, and Talismans in Early Medieval Japan: Chinese Influences on the Ritual Activities of Court Physicians
}

\author{
Alessandro Poletto
}

check for updates

Citation: Poletto, Alessandro. 2021

Pregnancy, Incantations, and

Talismans in Early Medieval Japan: Chinese Influences on the Ritual Activities of Court Physicians.

Religions 12: 907. https://doi.org/ 10.3390/rel12110907

Academic Editor: Jeffrey L. Richey

Received: 24 August 2021

Accepted: 8 October 2021

Published: 20 October 202

Publisher's Note: MDPI stays neutral with regard to jurisdictional claims in published maps and institutional affiliations.

Copyright: (C) 2021 by the author. Licensee MDPI, Basel, Switzerland. This article is an open access article distributed under the terms and conditions of the Creative Commons Attribution (CC BY) license (https:// creativecommons.org/licenses/by/ $4.0 /)$.
Graduate School of Letters, Kyoto University, Kyoto 606-8501, Japan; poletto.alessandro.72n@st.kyoto-u.ac.jp

\begin{abstract}
Court physicians (ishi or kusushi 医師), officials in the Bureau of Medications, were responsible for the well-being of court aristocracy since the establishment of a centralized state on the Japanese archipelago in the eighth century. Despite an increasing interest in the therapeutic arena of premodern Japan, scholars have tended to emphasize an epistemic divide between physicians and technicians employing other healing modalities, such as Buddhist monks and onmyōji 陰陽師, so that the former would be concerned with the physical body while the latter would not. However, this study focuses on the ritual and hemerological dimensions of the activities of court physicians within the crucial context of pregnancy and childbirth. By the twelfth century, court physicians affixed land-leasing talismans (shakuchimon 借地文) in the birthing room, pacified the birthing bed through incantations, and partook in the adjudication of a pregnancy-related hemerological notion known as hanshi (Ch: fanzhi). These practices appear in Ishinpo 医心方, which is a compendium of Chinese classics on therapeutics, hygiene, divination, and ritual that was compiled by Tanba no Yasuyori and presented to the court in 984 . Ishinpō incorporates elements from multiple continental traditions, and some of the ritual practices discussed in this paper have at times been framed as "Daoist". Since Daoist texts and institutions were never systematically brought or established in Japan, this study will rather stress the necessity of examining how Chinese textual traditions and ritual regimes were transmitted and distributed among institutions and technical groups within the Japanese state, in particular physicians from the Bureau of Medications and onmyōji from the Bureau of Yin and Yang.
\end{abstract}

Keywords: physicians; ritual; hemerology; pregnancy; onmyōdō; Japan

\section{Introduction}

The setting of the following two scenes is twelfth-century Japan, in the capital of the realm, Heian-kyō. On the first day of the eleventh month of the second year of Nin'an (1167), the head of the Medication Dispensary (Seyakuinshi 施薬院使), the physician Tanba no Norimoto 丹波憲基 (d.u.) was summoned by a court aristocrat, Fujiwara (or Kujō) no Kanezane 藤原 (九条) 兼実 (1149-1207), whose wife was at the time pregnant. We are told that Norimoto affixed a "land-leasing talisman" (shakuchi no hō 借地之法) on a beam of the room in which the birthing room had been provisionally set up. Kanezane writes that "this is [done according to] precedent," and that he was told that the land-leasing talisman had to be affixed on the first day of the month (Gyokuyō, vol. 1, p. 53).

On the twenty-eighth day of the fifth month of the second year of Gen'ei (1119), Fujiwara no Shōshi 璋子 (also read Tamako; 1101-1145), the consort of Toba Tennō, ${ }^{1}$ was in labor and expected to give birth that same day. The head of the Bureau of Medications (Ten'yaku no kami 典薬頭), the court physician Tanba no Masayasu 丹波雅康 (1081-1130), was summoned to set the bed consisting of straw mats on which the woman would give birth. On this occasion, he is also said to have "pacified" (鎮) the birthing bed through “incantations" (jujutsu 呪術) (Osan buruiki, vol. 1, p. 127).

Some readers may find the involvement of court physicians in the production and handling of talismans, and in the recitation of incantations, surprising. The actions of court 
physicians—officials in Bureau of Medications, in Japanese designated ishi or kusushi 医 師一are usually discussed, if not as medicine, as traditional Chinese medicine or $k a n p \bar{o}^{2}$ 漢 方; their purview is that of herbal or mineral concoctions, moxibustion, and acupuncture. However, in this paper, I will focus on some aspects of the toolkit of physicians that are generally neglected, namely their ritual and hemerological interventions. While it has long been recognized that texts such as Ishinpo 医心方 (Prescriptions at the heart of $i[j u t s u]$; presented to throne in 984) devote significant space to petty spells, incantations, talismans, hemerology, and divination, not many scholars engage in these aspects, and some focus instead on those that, for instance, are still well represented in the contemporary practice of traditional Chinese medicine, namely moxibustion and acupuncture. By combining an analysis of historical sources, Ishinpō, and other ancillary texts, I will make clear that the court physicians' ritual dimension did not merely exist on paper but can also be seen at work in the records of court aristocrats dating primarily to the twelfth and thirteenth centuries, in particular in the context of pregnancy and childbirth. Within this context, I will focus my attention on three moments: shakuchi(no)hō or shakuchimon (land-leasing incantation or talisman; the two terms are used interchangeably in sources), a ritual carried out on the first day of the due month; the setting up of the birthing bed once the woman had entered labor and delivery was deemed imminent (we have seen examples of both above); and the adjudication on the hemerological notion of hanshi 反支 (also read henshi; Ch: fanzhi), or "reverse branch".

These three moments are, as I mentioned, attested in numerous court journals from the early medieval period. They also appear in Ishinpo, a compendium in thirty scrolls on continental therapeutics compiled by Tanba no Yasuyori 丹波康頼 (912-985), ${ }^{3}$ instructor of needles (hari hakase 針博士) in the Bureau of Medications, and presented to En'yū Tennō in 984. In contemporary scholarship in both Japanese and English, Ishinpō has been studied primarily with regard to its second scroll, which deals with moxibustion and acupuncture-topics still today central to the practice of Chinese traditional medicine-and scroll twenty-eight, which covers the techniques and arts of the "bedchamber". ${ }^{4}$ However, despite its usual labeling, primarily among Japanese scholars, as a medical compendium (igakusho 医学書), Ishinpō is much more complex than that, as it also devotes sections and even entire scrolls to topics that concern ritual, divination, or hemerology. In this paper, I will examine some sections of scroll twenty-three, which is devoted to preparations for parturition, remedies, and strategies in case of difficult childbirth, the expulsion and handling of the placenta, and miscellaneous postpartum procedures. ${ }^{5}$ I will do so in order to shed light on the extent to which the ritual and hemerological dimensions of ijutsu have been neglected in modern scholarship, favoring an approach that, on the basis of morphological resemblances, suggests an equivalence between medicine and ijutsu.

My choice to utilize the term ijutsu rather than the more common "medicine" as a translation for $i$ 医 $^{6}$ is informed by my methodological stance toward modern epistemological taxa such as "medicine" and their uncritical application to non-modern contexts, in order to underline how this word usage obscures the substantial differences between what court physicians were doing and what medicine or igaku today designate. I will only be able to discuss a few concrete examples in this paper, but I will attempt some broader considerations in my conclusion.

Pierce Salguero (2018, p. 8, n. 10), in a discussion of $y i$ 医 in medieval Chinese Buddhist texts, has noted that the term is employed as a social rather than epistemological category; it designates a particular occupational group_-"physicians" — associated "with the bureaucratic class and a body of texts with antique pedigree," rather than medicine as an epistemological partition. The history of the transmission of $i j u t s u$ to the Japanese archipelago poses some additional difficulties—for instance, it was primarily Buddhist monks from the Korean Peninsula that contributed to the introduction of ijutsu-style therapeutic practices to Japan and to their establishment within the institutional structure of the early Japanese polity, which is known as ritsuryō 律令. However, by the period in question, it can be said that also in Japan, ijutsu had assumed similar associations, as the 
ritsuryō government had incorporated it within its bureaucratic structure, thus limiting who could learn and practice those therapeutic modalities.

Then, it is in a sense similar to that defined by Salguero that I use the concept of ijutsu in this paper. ${ }^{7}$

\section{The Context of Pregnancy}

Childbirth was a notoriously critical moment in the life of women and, more in general, for the households involved. Pregnancy-related deaths were a common occurrence, and a belief underpinning that state of affairs was that childbirth made women especially vulnerable to the attacks of malicious spirits, which in contemporary sources are often designated by the terms jake 邪気 (in Chinese-style kanbun writing) or mono no ke 物の気 (especially in vernacular sources, but later on in kanbun sources as well). Therefore, in particular when they involved powerful families or the birth of a potential future sovereign, pregnancy and childbirth were highly ritualized processes marked by a set of fixed moments that saw the participation of a plethora of specialists, including Buddhist monks, court physicians, and onmyōji-ritualists and diviners in the Bureau of Yin and Yang. ${ }^{8}$

Records concerning pregnancy and childbirth are almost entirely nonexistent in sources up until the late tenth and eleventh century, and they are generally scant afterwards-albeit with a few significant exceptions. This may account for the gap we notice between certain practices described in Ishinpō and their earliest occurrence in other historical records, such as the journals of court aristocrats, but I will return to issues of dating throughout this paper and in the conclusion. One of the most comprehensive accounts of pregnancy in premodern Japan can be found in Sankaiki 山槐記, the journal of the courtier Fujiwara (or Yamanaka) no Tadachika 藤原 (中山) 忠親 (1131-1195). The pregnancy in question is that of Taira no Tokushi 平徳子, the daughter of Taira no Kiyomori and consort of Takakura Tennō, who in the second year of Jishō (1178) became pregnant with a baby who would later become Antoku Tennō. Tadachika was at the time in charge of her affairs as supernumerary head of the secretariat of the sovereign's consort (chūgū gon no daibu 中宮権大夫). Studies in both Japanese and English have fruitfully used Tokushi's case to examine pregnancy and childbirth in early medieval Japan, ${ }^{9}$ but given their focus on a single episode, they offer a picture that is static and to a certain extent two-dimensional-a single article, no matter how detailed, can hardly do justice to such a panoply of activities spanning over months. It is for this reason that here I will delve into a narrow but deep examination of a few selected elements from the complex process of pregnancy and childbirth. ${ }^{10}$

Osan buruiki 御産部類記 (Thematic records on royal births), an early collection of excerpted passages drawn from a variety of journals concerning proper ritual and ceremonial procedures that had to be followed on the occasion of childbirth, covers a longer time span and includes quotes from sources that are otherwise no longer extant; as such, it is an irreplaceable source for the study of pregnancy and childbirth in ancient and early medieval Japan. ${ }^{11}$ In order to regain a sense of diachrony, then, I will integrate cases drawn from Sankaiki, Osan buruiki, and other early medieval journals-for instance, Hyōhanki and Gyokuyo- - to get a glimpse of the ritual and ceremonial practice as it was carried out on the ground. On the other hand, as mentioned before, I will also attempt to reconstruct the foundations of such practices and ideas, primarily utilizing Ishinpo as a touchstone, but also by looking at other texts (and, at times, traces of texts)—onmyōdo 陰陽道 ${ }^{12}$ manuals, in particular - to get a more inclusive sense of the landscape of the time. In this way, we will be able to see how continental_ "Chinese"13 — cultural forms were brought to the Japanese archipelago in a piecemeal fashion in a way that created overlaps between traditions and practitioners, and that was conducive to the establishment of niches that separately adjudicated on aspects of Chinese culture. ${ }^{14}$

\section{Talismanic Land Leases: shakuchimon}

In one of the vignettes above, we have seen Tanba no Norimoto, at the time the head of the Medication Dispensary, visit the residence where Fujiwara no Kanezane's consort 
Kenshi ${ }^{15}$ had been accommodated, on the first day of the eleventh month of the second year of Nin'an (1167). This was not the residence of Kanezane himself-it was customary at the time for high-ranking courtiers to have their consorts moved to the residence of a minor aristocrat, retainer, or other relative (often on the woman's side of the family) to avoid the effects of birth-defilement (san' $e$ 産歳) that the parturition event would engender. We have seen that Norimoto affixed a land-leasing talisman in the room-usually, in this period, the main room (moya 母屋) in the principal building of the residence in the shinden-zukuri 唚 殿造 architectural style-within which the birthing space had been set up. An interlinear note in the same entry of Gyokuyō, Kanezane's journal more specifically indicates that it was affixed "to the southern part of the upper tie beam" (Gyokuyō, vol. 1, p. 53). Kanezane then concludes that this was done according to precedent-a gloss that reveals that such a ritual procedure was at the time already established-and that, most likely reporting Norimoto's words, the talismanic lease had to be affixed on the first day of the month.

Norimoto makes another appearance under similar circumstances a few years later. In the third year of Shōan (1173), on the first day of the ninth month, he visited the residence to where Kenshi, Kanezane's consort who was at the time again pregnant, had been moved. On the basis of a previous entry, this can be identified as the house of Fujiwara no Sadayoshi 藤原定能 (1148-1209), Kanezane's brother-in-law. ${ }^{16}$ Norimoto, who at the time was still head of the Medication Dispensary, was summoned to Sadayoshi's residence, where he once again affixed a land-leasing talisman (shakuchihō) to the birthing place. Reporting Norimoto's words, the courtier also mentions that in this way, there would be “no abstention to observe within ten steps in the four directions 東西南北十步之中不可憚 云々" (Gyokuyō, entry for Shōan 3/9/1; vol. 2, p. 268).

As set forth in the first instance, the talisman had to be affixed on the first day of the month-more specifically, first day of the due month. This is reflected in both instances found in Gyokuyō: in 1167, Kenshi would give birth on the twenty-third day of the eleventh month; in the latter case, in 1173, a few days after the ritual, on the sixth day of the ninth month. One instance of shakuchihō found in Hyōhanki 兵範記, the journal of the courtier Taira no Nobunori 平信範 (1112-1187), suggests that in cases in which adjustments were deemed necessary, the ritual could also be carried out on a different day. The case in question is that of the wife of the lesser general (shōsho 少将) from Echigo (d.u.), a province in northern Japan that largely corresponds to the modern prefecture of Niigata. On the twentieth day of the fourth month of the third year of Kyūju (1156), Nobunori writes that the woman's labor began at dawn, and that for that reason, the head of the Office of Water Management (Shusuishi 主水司)—who was none other than the court physician Tanba no Motoyasu 丹波基康 (d.u.) -was summoned to affix a land-leasing talisman (here called shakuchimon 借地文). Given the urgency of the situation, the execution of the ritual lease could not be delayed. In terms of space, there was some flexibility-in Sankaiki, the journal of Fujiwara no Tadachika, we see that since there was no space in the main room (moya) for the talisman, it was affixed to the northern tie beam in the northern part of the hisashi 比, the roofed corridor space that surrounded the main room in the shinden-zukuri style. ${ }^{17}$

These four examples, the earliest occurrences of land-leasing talismans employed on the occasion of pregnancies I have been able to ascertain, are all concentrated in little more than twenty years, spanning from 1156 (Hyōhanki) to 1178 (Sankaiki). Somewhat perplexingly, there is no mention of shakuchimon in earlier historical sources-either official histories or courtier diaries; it does not appear in the Kōgu osan tōjitsu shidai 后宮御産当日次 第 (Procedures for the day of childbirth of royal consorts), a handbook of ritual procedure to be observed following a royal consort's labor compiled probably in the thirteenth century on the basis of earlier records; and for it to make another appearance, we have to turn to the writings of Saionji Kinhira 西園寺公衡 (1264-1315), and in particular the two bekki 別記 ("separate records"; self-standing sections of journals covering in detail specific episodes or thematically homogeneous series of entries) in which he minutely reported the pregnancies of his sister Eishi 瑛子 (also read Eiko; 1272-1336), who married Kameyama Tennō and is better known under her honorific soubriquet Shōkunmon'in 昭訓門院, and his daughter 
Neishi 寧子 (also read Yasuko; 1292-1357), who married Gofushimi Tennō and is better known under her soubriquet Kōgimon'in 広義門院. ${ }^{18}$ In Shōkunmon'in osan guki 昭訓門 院御産愚記 (“Foolish record on the childbirth of Shōkunmon'in", 1303 [Kengen 2]; guki is a humble term used by some to refer to one's writings), we read that in an entry dated the second day of the intercalary fourth month that the previous day, the physician Tanba no Yukinaga 行長 had affixed a land-leasing talisman to a tie beam in the northern side of the room, but that he had also affixed other talismans (札符) to other directions. In an interlinear note, Kinhira quotes Yukinaga's word, "Depending on the position of Nichiyū 日遊, the land-leasing talisman should be affixed again" (Kinhira kōki, vol. 3, p. 63). I will discuss Nichiyu's role within the context of childbirth in the next section, but here, it will suffice to say that it is one of a series of calendrical itinerant deities, whose presence in a certain direction or place could be deemed propitious or ominous. What we see here is that by the early fourteenth century, the practice of shakuchimon had to some extent changed: multiple talismans are affixed in the first place, so that the use of shakuchimon is combined with other unspecified talismanic forms of protection; and the shakuchimon itself needed to be replaced or moved on the basis of the motion of Nichiyu. This is confirmed by a short description found in Kōgimon'in osan guki 広義門院御産愚記 (“Foolish record on the childbirth of Kōgimon'in; 1311 [Engyō 4]), in which Kinhira writes that Yukinaga affixed the land-leasing talisman not only to a pillar but also to Gōkimon'in's high pillow (Kinhira kōki, vol. 3, p. 214).

The practice of affixing land-leasing talismans to the birthing place on the first day of the expected due month is attested in a number of handbooks and technical texts, but given the status of those involved in the performance of the ritual—namely, court physiciansand the specifications of the talismans mentioned in the sources discussed above, its most likely source for the cases in question is Ishinpō, the compendium of continental ijutsu compiled by Tanba no Yasuyori in 984. Indeed, section four of scroll twenty-three is entitled “On land-leasing for parturients (産婦借地法)". Here, Yasuyori quotes the Zimu milu 子 母秘録 (Secret records on children and mothers), which is a Tang period collection on obstetrics and pediatrics attributed to Xu Renze 許仁則 (d.u.) in the Tong zhiyi wenlüe (Brief bibliography of the comprehensive treatises) and to Zhang Jie in the Songshi yiwenzhi (Bibliographic treatise in the History of the Song) (Zheng et al. 2018, pp. 551-52). This quote consists of a passage drawn from an unknown source named in the text as the "method of Tixuanzi 體立子法," namely, "the land-leasing talisman that, [on the occasion] of the leasing of the land for parturients, removes the hundred abstentions". It starts by invoking the need to lease ten steps in the four directions within the birthing place but also above and underneath it. What makes this action necessary is the fear of defilement (歳污) caused by the parturition and its related discharge of unsavory (to a variety of deities, at least) fluids. Deities from Chinese lore-including the "spirit kings" (神王) of the four seas, Shōgun and Nichiyū —are asked to move aside ten $j \bar{o}$ 大, while the celestial dog (tiangou 天狗) is asked to enter ten $j \bar{o}$ into the earth. It ends with a formula traditionally found in talismanic writing, “kyūkyu nyo ritsuryō 急急如律令," or “[do so] with most haste, in accordance with the ritsuryō codes". ${ }^{19}$ An interlinear note provides instructions on how to produce and employ the talisman: "On the first day of the month, transcribe one copy [of the talisman], chant [the formula] three times and, at the end, affix it at the center of the northern wall of the place where [the pregnant woman] is staying".

Originally, written on the back of scroll twenty-three-but today hardly visible because of layers of paper applied to the aging Nakaraike manuscripts on occasion of repairs-there is what seems to be a sample land-leasing talisman. The text is that found also in the main body of Ishinpō, based on the "method of Tixuanzi" quoted in the Zimu milu. However, in addition to that, we see two fulu 符籙 (lit., "talismans and registers"), which is a type of talismanic writing consisting of complex combinations of strokes that resemble Chinese characters while not, strictly speaking, holding phonetic or semantic value, respectively to the left and right of the text; a gloss specifies that they are both to be written in red. 
On the basis of this analysis of Ishinpō and of the instances of shakuchimon recorded in early medieval journals, it is clear that the function of the land-leasing talisman is that to create a safe space within which the standard rules of defilement do not apply. The performance of the ritual of shakuchimon-which, on the basis of Ishinpo, seemed to also include a verbal section that is not recorded elsewhere-creates a place suitable for childbirth out of an ordinary space by leasing it from the deities that usually dwell in it. The birthing place is not merely a house within which certain temporary structures-using folding screens and curtains - are put up, but a space that has to, first of all, be ritually prepared. The creation of the birthing place, narrowly defined, starts symbolically with the performance of shakuchimon and, only afterwards, takes concrete form. The deities mentioned in the text of the talisman are not a standard part of any Japanese pantheon, but it is possible that the procedure was seen as effective also at keeping domestic deities at bay, since defilement was also believed to negatively affect local deities-kami, for instancewho, in response, might have cursed those who had caused the "spill". ${ }^{20}$ Naturally, the land lease in question was believed to possess talismanic force, so it is also possible that it functioned more generically as an apotropaic or defensive mechanism.

Since between the appearance of shakuchimon in Ishimpo and its later occurrence in twelfth-century journals there is a gap of over a hundred years, we might be tempted to conclude that the ritual only existed on paper until the twelfth century, when it was finally dusted off and put into practice. However, once we look elsewhere, we find hints that complicate this neat chronological picture. In the Onmyō kikkyō shō 陰陽吉 区抄一a compilation of calendrical notations on auspicious and inauspicious days, and miscellaneous records on activities in which onmyōji were involved, likely compiled in the second half of the thirteenth century (Takada and Takuma 2001, pp. 232-35)—we find mention of a "land-leasing incantation for parturients". The text of the formula itself is, except for a couple of characters, the same as that seen in Ishinpō, but there is a gloss in the Onmyō kikkyō shō following the final "kyūkyū nyo ritsuryo". It reads: "In Rekirin 暦林, it is said: on the first day after entering the [due] month, transcribe one copy [of the talisman], chant [the formula] three times and, at the end, affix it at the center of the northern wall of the place where [the parturient] is staying" (p. 228). Other than minor differences, which have no bearing on the meaning of the gloss (and its translation), the interlinear notes in Ishinpō and Rekirin are the same.

Rekirin (Thicket of calendrics) is the title of a text compiled by the famed onmyojii Kamo no Yasunori 賀茂保憲 (917-977). The text of Rekirin is no longer extant, and it is only available to us in a fragmentary fashion as quoted in other records, as in this case. However, what is clear is that the shakuchimon text there collected cannot be based on Ishinpō, as the compilation of Rekirin preceded that of Yasuyori's compendium. The interlinear glosses found in both texts present an additional challenge: is it possible that both texts are based on the same source, which may very well be the Zimu milu utilized by Yasuyori? That text is cited in Rekirin, in a different section, which is a fact that we can once again ascertain thanks to a quote in Onmyō kikkyō shō. ${ }^{21}$ However, it should be noted that other Chinese ijutsu texts make mention of shakuchimon, for instance the Waitai miyaofang 外台秘要方 (Secret essential recipes from the Outer Censorate), a Tang period compilation of ijutsu put together by Wang Tao. In scroll thirty-three, we see a quote from Tixuanzi-the same source cited in Ishinpō. Despite this, the texts are considerably different-the formula in Waitai miyaofang is shorter; the reference to "defilement" in Ishinpo cannot be found in Wang Tao's text, where we read that "in that place, there will be no hindrances, nothing to fear or abstain from. The many deities will offer protection (諸神擁護), the hundred malicious spirits will promptly retreat (百鬼早去). With most haste, in accordance with the codes!" However, the practical instructions are the same: the talisman is to be copied on the first day of the due month and affixed at the center of the northern wall of the birthing room (p. 665).

While is it impossible to ascertain the source of the citation in Rekirin and to solve the puzzle constituted by all these textual pieces, this snippet quoted in Onmyō kikkyō shō 
ultimately reveals to us the limitations of the textual materials we have at hand today. Already in the tenth century, shakuchimon was of concern, as the fragmentary records of one of the leading onmyōji of the time shows-a quote that, incidentally, also suggests that, at least until (or during) Yasunori's lifetime, onmyōji might have been involved in the production and utilization of shakuchimon. Its absence elsewhere may tell us more about the practice of record keeping and its male-centered ethos rather than the utilization of land-leasing talismans in ancient and early medieval Japan..$^{22}$

\section{Calendrical Adjudications: hanshi (and Nichiyū)}

Once the space necessary to set up the birthing room was cleared from the presence of numinous entities who might be displeased with the presence of childbirth-caused defilement, the next step was to actually erect the birthing room, which in the period in question consisted of a space demarcated by folding screens, bamboo screens (sudare 策), and curtains. However, before that, there were calendrical calculations to undertake and some hemerological adjudications to make. In this context, we once again see the nature of the relationship between onmyōji and court physicians with regard to how ritual and hemerological culture imported from China was split between the two in a way that was flexible and unsystematic. In this section, I will focus in particular on a moment of this phase of the childbirth process: the adjudication on whether an inauspicious hemerological marker known as hanshi (or henshi; Ch: fanzhi), which can be translated in English as "opposite branch" or "reverse branch," was operative in the time frame of parturition. I will also mention the calculations surrounding the location of Nichiyū-one of a set of deities believed to circulate on the basis of regular calendrical patterns and affect the action of humans depending on its position-within the house in which the childbirth would take place.

The account found in Sankaiki, the aforementioned journal of the courtier Fujiwara no Tadachika, concerning the pregnancy of Taira no Tokushi, is among the most detailed surviving records on hanshi. However, it is also a bit unusual under one aspect: while conversations on hemerological adjudications on Nichiyu and hanshi were generally carried out once the pregnant woman had entered labor, in this case, they take place for the first time on the twenty-seventh day of the tenth month, but Tokushi would not give birth until the twelfth day of the following month. Tokushi's pregnancy seems to have proved difficult to fathom for most technicians of early medieval Japan: something that is demonstrated, among other things, by the fact that the land-leasing talisman for Tokushi was affixed on the first day of the tenth month ${ }^{23}$ —clearly, Tokushi was expected to give birth within that month, which is why such issues were being discussed at that stage (the eleventh month of the second year of Jishō was a "short" 29-day month). Therefore, in Sankaiki, we see this conversation happen twice, once on the twenty-seventh day of the tenth month and once on the twelfth day of the eleventh month, the day of Tokushi's labor. Both accounts offer precious information on how calendrical calculation on Nichiyu and hanshi were handled.

On the first occasion, the head of the Bureau of Yin and Yang, Kamo no Arinori 賀 茂在憲, when asked about hanshi and the propitious direction to face during childbirth, "responded that it should be a direction free from impediments from Nichiyū and hanshi, but concerning this issue, court physicians (ike 医家) should also be consulted. Therefore, we asked the head of the Bureau of Medications [Wake no] Shigeyasu ason, who said the same thing as the onmyojii". (Sankaiki, vol. 2, p. 157). ${ }^{24}$ The second instance is dated the twelfth day of the eleventh month. After Tokushi's labor had begun, onmyōji were asked about the location of Nichiy $\overline{\mathrm{u}},{ }^{25}$ and the result of their calculation was that it was not in the moya, which is why the birthing bed was set up there. Then, the head of the Bureau of Medications Wake no Shigeyasu was asked about hanshi, and his adjudication was that that day, hanshi was not applicable (今日不相當). On this occasion, we also learn what measures would have been necessary if the hemerological marking hanshi had been active: "In cases when doy $\bar{o}^{26}$ or hanshi apply, one has to first spread two pieces of cowhide side by side; on top of that, one has to spread ashes; on top of that, one has to lay out a silk cloth; on top of 
that, one has to spread the birthing mat. But today hanshi was not applicable, therefore, although those items were prepared, they were not spread" (Sankaiki, vol. 2, p. 164).

The fundamental features of this process-its timing, the division of labor between onmyōji and physicians, the objects to prepare in case of childbirth at a moment in which hanshi was operative - can be confirmed for example by looking at the Kōgū osan tōjitsu shidai. This condensed record of ritual procedures was compiled as a handbook on the basis of previous records. It begins, following the indication of the pregnant woman undergoing labor, with the inquiries concerning the whereabouts of Nichiyū and the status of hanshi. The preparation of the birthing bed includes mention of Nichiy $\bar{u}$ once again: if he is not in the moya, as seen in Sankaiki above, the birthing room and bed will be set up there, but if the itinerant deity is located there, then the woman will be moved to the hisashi (the roofed corridor space that surrounded the core room or moya) and-it is noted in the Kōgu osan töjitsu shidai-more specifically, to the northern hisashi. In a passage that largely mirrors the one seen in Sankaiki (with some minor differences), we also see mention of what should be prepared in case of doyo or hanshi: one sheet of cowhide, ashes to be scattered on it, and finally a silken cloth, ${ }^{27}$ on top of which the birthing mat should be set up (Kōgū osan tōjitsu shidai, p. 542).

The practice of layering cowhide, ashes, and silk under the birthing mat in case of hanshi is attested also in Sanchōki 三長記, the journal of the courtier Fujiwara no Nagasane 長実 (fl. 1191-1211), a mid-rank courtier who served under Fujiwara no Kanezane and his son Yoshitsune. On the occasion of the pregnancy of Kanezane's daughter Ninshi 任子 (also read Taeko, and also known as Gishūmon'in 宜秋門院; 1173-1239)—who was also the consort of Gotoba Tennō-Nagasane writes in an interlinear note that "today hanshi is applicable, therefore they spread a sheet of cowhide; on top of it, they scatter ashes; on top of that, they spread one roll of silk, a hundred $r y \bar{o}^{\prime \prime}$. Finally, the birthing mat is laid out (Sanchōki, entry for Kenkyū 6 [1195]/8/13; p. 187).

As for the calculations concerning Nichiyū's presence within the moya of the house chosen for the pregnant woman to give birth, other sources from this period make clear that the choice was binary-if Nichiyu is in the moya, then the birthing room will be set up in the hisashi; otherwise, it will be erected in the moya. Therefore, Nichiyu's absence from the moya had to be ascertained through consultation with onmyōji. Kanezane writes in his journal that "on the basis of the location of Nichiy $\bar{u}$, [the birthing room] will have to be decided between moya and hisashi (又随日遊所在、可定母屋庇)" (Gyokuyō, entry for Shōan 3/9/1; vol. 2, p. 268). Taira no Nobunori, in an entry of his journal Hyōhanki, already discussed the above for its treatment of shakuchiho, writes that at first, the wife of the lesser general from Echigo had been placed in the northern hisashi to give birth, but later, they were informed that Nichiyu would not be in the moya on that day and the following day, and they were told that they would have to establish the birthing room in the moya within ten steps from the shakuchimon that had been affixed there by Tanba no Motoyasu (Hyōhanki, entry for Kyūju 3/4/20; vol. 2, p. 98). Since nobody else is mentioned on this occasion-no onmyōji seem to have present at the scene-it is possible that it was the physician who provided information on the whereabouts of Nichiy $\bar{u}$. These instances allow us to see that despite scarcity in sources, there was a certain level of consistency in how the adjudications concerning Nichiyū and hanshi were handled.

Discourses on these calendrical categories exist in a complex network of texts spanning traditions and centuries, but while in the case of Nichiyu it is hard to put together a textual genealogy, with regard to hanshi, the involvement of court physicians and the descriptions examined above allow us to once again identify Ishinpo as their textual reference. As a matter of fact, we find mention of Nichiyū as well in Ishinpō: in the first section of scroll twenty-three, entitled "On how pregnant women should sit and where they should face [for childbirth]," Yasuyori quotes from an unidentified text called Sheng jing 生経 (Birth canon?), and one of the passages drawn from this text urges physicians, whenever a woman gives birth or breastfeeds, to first carefully examine the charts of the twelve month deities (十二月 神圖) so that she can face the proper direction once the positions of Ten'itsu 天一, Nichiyu 
and the eight itinerant deities (八将神) who preside over auspicious and inauspicious directions have been ascertained (Ishinpō, vol. 5, p. 1973). Unfortunately, Yasuyori writes that the charts are too complex and thus does not reproduce them (ibid.), so that in Ishinpo, we only find simplified versions for each month. Nichiyu does not appear again, and it is hard, on the basis of this passage, to grasp to what extent physicians well-versed in Ishinpo $\bar{o}$ were capable of making calculations concerning Nichiy $\bar{u}$, despite mentions in some of the twelfth-century journals that have been examined above. It is worth noting that Nichiyū appears already in the Waitai miyaofang, the Tang-period ijutsu compendium, where we also see a chart detailing its movements and positions (p. 665), which is a fact that shows a connection between the deity and ijutsu, but Yasuyori did not include that material in Ishinpō.

Nichiy $\bar{u}$ is traditionally considered a retainer of Ten'itsu, another itinerant calendar deity, but its early history is obscure. We see mentions of Nichiyū in a fragmentary guchüreki 具注暦 (almanac with ritual and calendrical notations) preserved as Shōsōin and dated 756 (Tenpyō Shōhō 天平勝宝 8), in which his connection with pregnancy is already established, and in the autograph manuscript of Midō kanpaku ki 御堂関白記, the journal of Fujiwara no Michinaga 藤原道長 (966-1028) and the oldest extant journal written on a guchūreki, we see systematic annotations on the days in which Nichiyu was believed to be "inside" (日遊在 内), but there are no remarks about Nichiyu in the journal itself and no discussion of his presence in connection with pregnancy and childbirth in any contemporaneous sources. We do find one mention in Shōyūki 小右記, the journal of Fujiwara no Sanesuke 藤原央 資 (957-1046), where we read that while Ten'itsu, as part of its cycle, resided in the sky, Nichiyū descended on earth and resided inside the house; during that period, construction work was to be avoided (entry for Chōwa 3 [1014]/3/6; vol. 3, p. 197). ${ }^{28}$

Much more extensive is the discussion of hanshi we see in section two of scroll twentythree of Ishinpo, which displays a degree of complexity that would have been hard to grasp from the instances examined above. Yasuyori's treatment of hanshi is entirely based on a single text, Chan jing 産経 (Canon of birth), which in the Nihonkoku kenzaisho mokuroku 日本 国見在書目録 (Catalogue of [Chinese] books available in Japan), compiled by Fujiwara no Sukeyo 藤原佐世 (847-897), is attributed to a certain De Zhenchang 徳貞常 (sixth century?) (p. 46). The text is no longer extant, and it is only through the extensive quotes that we find in Ishinpō that part of its content can be retrieved. An introductory passage from Chan jing reads:

Hanshi (Ch. fanzhi; "reverse branch") is given this name because [the earthly branches] make one round and return [to the initial branch], thus harming people. If a woman gives birth or breastfeeds violating [hanshi], she will certainly die. One has to act with restraint. If childbirth or breastfeeding occur during a hanshi month, one will have to rest upon cowhide or ash. Defiled fluids, blood and other foul things must not be allowed to touch the earth. If they touch the earth, one will die. In addition, one should wash all [that was expelled] and store that in a vessel and leave it untouched until the end of this ominous month. (Ishinpō, vol. 5, p. 1977)

This is followed by four sections in which four different types of hanshi are introduced. The first is based on the earthly branch under which the year begins: if the year begins in rat (ne 子; $\mathrm{Ch}: z i$ ), then the earthly branch monkey, which corresponds to the seventh month, will be inauspicious; if the year begins in ox (ushi \#; $\mathrm{Ch}$; chou), then rooster, which corresponds to the eighth month, will be inauspicious; and so on, following the order of the twelve earthly branches. The second depends on the age of the parturient, ranging from thirteen to forty-nine. The third is based on the earthly branch of the year in which the parturient was born: if she is born in a rat year, then her hanshi month will be the first month; if she is born in an ox year, her hanshi month will be the twelfth month; if she is born in a tiger year, then her hanshi month will be the eleventh month; and so on. The fourth and last type of hanshi applies to the day rather than the month; if the earthly branch associated to the first day of the month is rat or ox, then the sixth day will be a hanshi day; if 
the first day of the month is tiger (tora 寅; Ch: yin) or hare ( $u$ 卯; Ch: mao), then the seventh day will be a hanshi day; and so on (Ishinpō, vol. 5, pp. 1977-80).

While the mention of the cowhide and ash is largely in agreement with the descriptions found in Sanchōki, Sankaiki, and elsewhere, the existence of four different types of hanshi is not articulated in any of the scenes we have examined above. Whether physicians engaged in the calculation of a specific kind of hanshi or of all four is something that is impossible to claim with any certainty. In some instances, courtiers write that "today" hanshi is or is not operative, which would suggest that at least in those cases, it is the fourth type of hanshi introduced in Ishinpo that is being considered (but see below for a more explicit, albeit older, record).

At any rate, there are a few considerations that I would like to make. The first is that all four hanshi are hemerological marks - the propriety or success of certain actions (in this case, childbirth) is defined in connection to its place within a calendrical system. This adjudication is made, in Ishinp $\bar{o}$ and in the twelfth century, by court physicians, which shows the close connection that existed between ijutsu and hemerology. The Chan jing quoted by Yasuyori is a collection on obstetrics that contains abundant hemerological topics; but beyond Ishinpō and Chan jing, hanshi hemerology can also be found in other important Chinese classics of ijutsu, for instance Waitai miyaofang, the Tang period compendium edited by Wang Tao, which in scroll thirty-three includes a version of the age-based hanshi (Waitai miyaofang, pp. 658-661), which is however not based on Chan jing-no citations from this text appear in Waitai miyaofang-and differs in some regards from that found in Ishinpō; and in Qianjinfang 千金方 (Recipes worth a thousand in gold), a compendium of Tang and pre-Tang ijutsu compiled by the legendary physician Sun Simiao 孫思邀 (d. 682), which in section five (産難; “Difficult childbirth”) of scroll two (婦人方; “Recipes for women") includes a brief mention of hanshi and, similarly to Ishinpō, instruction on how to act in case childbirth or breastfeeding occurred during a hanshi month (Qianjingfang, p. 98). However, Qianjinfang does not provide any instruction on how to calculate hanshi. These examples show that hemerological elements were incorporated into ijutsu already in China by the Tang period, and that same attitude also informs the action of court physicians in early medieval Japan. ${ }^{29}$

That said, as already noted in our discussion of the appearance of shakuchimon, once we look more broadly at the reception of hanshi and its connection with childbirth on the archipelago, we find hints of a more complicated history beyond Ishinpo and continental texts. In the Onmyō kikkyō shō, the compilation of hemerological annotations and other onmyōdō-related topics, we find an entry on hanshi, which is an unremarkable fact in itself. However, a short preface informs us that according to the compiler of Onmyō kikkyō shō, hanshi was originally “onmyōdō's business (陰陽道沙汰)," but that at the time of Yoshihira, its handling switched to "idō 医道," namely court physicians, who had overseen it ever since (p. 228). The Yoshihira mentioned here is Abe no Yoshihira 安倍吉平 (954-1026), the son of the legendary onmyōji Abe no Seimei and one of the most prominent figures in onmyōdō at the time, which would put this switch in the adjudication of hanshi from onmyōji to court physicians sometime in the late ninth or early tenth century.

For a lucky coincidence, we have a passage dating back to that time that concerns hanshi. It is the only pre-twelfth century record on hanshi that I have been able to retrieve in non-technical literature-namely, in texts that are not prescriptive and were not written for the education of onmyōji or other specialized figures. It is recorded in Sakeiki 左経記, the journal of the courtier Minamoto no Tsuneyori 源経頼 (985-1039); on the third day of the twelfth month of the third year of Manju (1026), on the occasion of the pregnancy of Fujiwara no Ishi 藤原威子 (also read Takeko; 1000-1036)—daughter of Michinaga and Ichijō Tennō's consort, Abe no Yoshihira and Kamo no Morimichi were summoned and asked about hanshi and whether it would have a bearing on Ishi's parturition. In his report, Yoshihira writes:

The year began under [the earthly branch] boar. It is not yet time for hanshi; it is in the sixth month that pregnancy should be avoided. As for [her] age, she 
is twenty-eight; hanshi will be of concern in the fourth and tenth months. For a person who was born in the year of the boar, hanshi will be in the second month. On the basis of the first day of this month [and its associated earthly branch], the second day is hanshi. Therefore, this month there is no hanshi to be concerned about. (Sakeiki, p. 197)

This passage is of great interest. It confirms that all hanshi were taken into consideration when adjudicating on inauspicious time frames for childbirth, but a comparison with Ishinpo reveals a substantial correspondence between the system utilized by Yoshihira and that based on Chan jing and adopted by Yasuyori. ${ }^{30}$ This suggests the possibility that both Yoshihira and Yasuyori relied on the same source-namely, the Chan jing. Following a trail of fragmentary textual clues reinforces this possibility.

First, fast forwarding about a hundred and fifty years, back to Sankaiki and its account of Taira no Tokushi's pregnancy, we find a succinct remark: since Tokushi's childbirth was proving difficult, one of the measures undertaken to facilitate the delivery was the opening of the east gate, which had been left closed the entire day, which is a custom also attested in Ishinpō. This practice was found, we are told, in Rekirin, in the scroll on Chan jing (此事見暦 琳産経巻). ${ }^{31}$ As the reader will recall, Rekirin is the title of the no longer extant compilation on calendrics compiled by Kamo no Yasunori in the tenth century; this mention in Sankaiki would indeed show that onmyōji had access to the Chan jing already in the tenth century, and that they utilized it in their mantic activities-which is hardly surprising, given the markedly hemerological character of some of its surviving passages. Katsuura (2008, p. 11) has also noted how the Chan jing is mentioned in Utsuho monogatari 宇津保物語 (Tale of the hollow tree), which is one of the earliest surviving monogatari and probably written in the second half of the tenth century, in a scene in which it is consulted by one of the characters to predict the sex of the baby of Ichinomiya 女一宮, and to instruct her on what to eat during the rest of her pregnancy (Utsuho monogatari, vol. 2, p. 332). Despite the fictional nature of the work, this passage shows that already in the tenth century, there were courtiers who had the Chan jing in their libraries, so that its mention in a piece of literature would not have escaped them. As a piece of technical literature, it must have attracted the attention of onmyōji early on, as one can note from the roughly contemporary case of Yasunori. While it is unclear whether in Rekirin there was an entirely scroll devoted to Chan jing or just a section, its presence within a canonical onmyōdō text is nevertheless clear.

However, in the continuation of the above passage from Sakeiki, we also see the report submitted by the other onmyōji who had been summoned on this occasion, Kamo no Morimichi. Morimichi writes that there are seven types of hanshi and notes that his calculations do not agree with Yoshihira's - he says, for instance, that the hanshi of a twentyeight-year-old woman is in the twelfth month, the month when Ishi was expected to give birth. The disagreement between the two caused frustration, and they were asked to verify their sources and submit a new report. Two days later, on the fifth day of the twelfth month, Morimichi presented a new report (Yoshihira did not because, we are told, he was sick. He would eventually pass away two weeks later, on the eighteenth day of the twelfth month). After checking the old reports penned by Shigeoka no Kawahito 滋岳 川人 (but written 滋岡 in the passage in question; d. 874), an onmyōji active in the early Heian period, Morimichi writes that hanshi based on the age of the parturient is particularly severe, and that for this year, Yoshihira's calculations in that regard were right- the fourth and tenth month were to be avoided. Kawahito was a famed figure within onmyōdō and at court for his mantic prowess, ${ }^{32}$ and the fact that he left behind official reports (kanmon 勘文) indicates that during his lifetime-mid- to late-ninth century-hanshi on occasion of pregnancy and childbirth was already of concern. The appearances of Shigeoka no Kawahito and his kanmon, of Kamo no Yasunori and his Rekirin, and of Abe no Yoshihira and Kamo no Morimichi on the occasion of Fujiwara no Ishi's pregnancy also confirm the gist of the observation in Onmyō kikkyō shō: hanshi was originally within the purview of onmyōji, but at some point in time, its handling switched over to court physicians. Ishinpo was presented to the court in 984, a few decades before the vignette in Sakeiki; whether it 
was on the basis of its presentation of hanshi as part of ijutsu that this shift took place, it is hard to say.

In any case, and despite the fragmentary nature of many of the records mentioned here, what we see once again is the complexity of cultural transmission at work, and, more specifically, how the importation of continental culture-in this case, Chinese hemerologyto the Japanese archipelago took place in a rather unsystematic fashion and through multiple channels. One would be tempted to see calendrics and hemerology as the exclusive purview of onmyōji-who were, after all, in charge of producing the yearly annotated calendar in use at court, but, as noticed above, hanshi hemerology had deep roots in ijutsu as well. By the twelfth century, what we see at work is a functional division of labor between onmyōji and physicians with regard to calendrical and hemerological adjudications in the context of pregnancy: Nichiyu was the purview of onmyōji; hanshi, of physicians. The range and complexity of the ritual and hemerological dimension of $i j u t s u$ is conveyed in Ishinp $\overline{0}$ and, in some aspects, reconfirmed in the activities of court physicians.

\section{Setting Up the Birthing Mat: Incantations}

Once the birthing area had been freed from the presence of deities who may abhor the defilement engendered by childbirth and its foul fluids through the use of land-leasing talismans, and once, after labor, hemerological adjudications had been made on the applicability of hanshi to the expected month and day of birth, it was time to finally and materially set up the birthing room, which consisted of mats surrounded by layers of folding scrolls, bamboo scrolls, and curtains. As we have seen in the previous section, the area within a residence where the birthing room would be set up depended on the position of Nichiyū: if the itinerant deity was inside the house, then the birthing room would be built in the hisashi; otherwise, it would be set up in the moya. Depending on whether the hemerological marker hanshi was operative on the day in question, setting up of the birthing room could require additional steps: a layer of cowhide, followed by ashes and, in some cases, another layer of cloth-but this step cannot be found in ijutsu literature and was, later on, often omitted-followed by the actual birthing mat. However, the spreading of the birthing mat does not seem to have been perceived as a merely pragmatic step involving ordinary objects. Indeed, it was another ritual occasion in the long chain of events that marked pregnancy and childbirth, and the ritualists tasked with this role were, once again, court physicians, either from the Bureau of Medication or the Medication Dispensary.

We have already seen an instance of this ritual in one of the vignettes at the beginning of this paper: Fujiwara no Shōshi, consort of Toba Tennō and pregnant with the future Sutoku Tennō, was in labor. The physician Tanba no Masayasu, the head of the Bureau of Medications, was summoned so that he could set up the birthing mat on which the tennō's consort would give birth. At this point, we are told that he "pacified the [birthing] mat utilizing incantations (jujutsu)". This account is found in a journal that is today no longer extant; in some sources, it is called Genreiki 源礼記, which is fortuitously quoted, together with other now scattered records, in Osan buruiki (Thematic records on royal births), a collection of excerpted passages drawn from journals dealing with pregnancy and childbirth, and all relevant ritual procedures. This entry dates from 1119, which makes it the earliest occurrence (among those recorded and still extant) of birthing bed incantation. The term jujutsu is in modern scholarly jargon used primarily to designate esoteric Buddhism and its rituals, but in this passage from Genreiki, and more in general in contemporaneous usage, it indicates ritual interventions that involve the reading or recitation of a formula, as in this case-what we may call a type of speech act.

The court physician Masayasu makes another appearance under similar circumstances a few years later, in a passage once again recorded in Osan buruiki, which is also the second oldest extant record of birthing bed incantation. The entry in question consists of a quote from Kyūminki 九民記, the journal of the courtier Fujiwara no Akiyori 藤原顕頼 (1094-1148), which, similarly to Genreiki, has not survived to these days. On the eleventh day of the ninth month of the second year of Daiji (1127), we first see cowhide, ashes, and then two 
pieces of white cloth being spread-but it is unclear whether on this occasion hanshi or doyō applied, most likely because that piece of information was provided in a passage that, because of damage to the manuscript, is no longer readable. Afterwards, the head of the Bureau of Medications Masayasu turned up, read an incantation (読呪), and left (vol. 2, pp. 11-12).

Despite the fact that these two instances appear relatively early in written records, subsequent cases of birthing bed incantations are rare and scattered. To find another occurrence, we have to turn once again to Sankaiki and its extremely detailed treatment of Taira no Tokushi's parturition. Despite Tadachika's intricate descriptions and concern for minutiae, in this case, we are simply told that Wake no Shigeyasu, at the time the head of Bureau of Medications, after being asked about hanshi, read the text of the incantation (読 呪) and left (Sankaiki, vol. 2, p. 164).

While it is undeniable that the scarcity of sources constitute a limit for our analysis, the fact that the birthing bed incantation was a standard element within the childbirth ritual program is also confirmed by its inclusion in the Kōgū osan tōjitsu shidai, the handbook-like compilation of ritual procedures that were to be followed after the onset of labor, where we read that "a physician comes and reads a record (読記);" afterwards, five pieces of mat lined with white cloth are spread - this is the birthing bed. An interlinear note adds the name Norimoto to this record, which suggests that this passage is based on a text in which the court physician and head of the Medication Dispensary Tanba no Norimoto had been tasked with the performance of the incantation. While his exact dates are not known, Norimoto was active in the second half of the twelfth century; interestingly, there does not seem to be any extant sources in which we see him conduct the birthing bed incantation. For instance, Norimoto appears in Gyokuyō on two occasions in the context of pregnancy rituals; in both occasions, we see him affix land-leasing talismans. The passage in the Kogg $\bar{u}$ osan tōjitsu shidai is in all likelihood based on an account roughly contemporaneous with those in Gyokuyō but that has not reached us. The birthing bed incantation also appears in some later sources, but it is essentially unchanged: in Kinsuke kōki 公相公記, the journal of Saionji Kinsuke 西園寺公相 (1223-1267)—no longer extant, quoted in Osan buruiki一the head of the Bureau of Medications Tanba no Tadanaga read an incantation and left (Kangen 5 [1247]/10/9; Osan buruiki, vol. 2., p. 106); in Kōgimon'in osan guki, Saionji Kinhira notes that a physician - his name is illegible-was summoned, read an incantation, and left (Engyō 4 [1311]/2/23; Kinhira kōki, vol. 3, p. 209).

The accounts examined here span almost two centuries, but despite that, the ritual itself does not seem to have undergone any changes over time. We have seen that the talismanic land lease of shakuchimon and the hemerological adjudications on hanshi were to some extent disputed-shakuchimon appears in a handful of onmyōdō texts, although onmyōji do not appear, on the ground, to have been involved in its enactment (at least in the relatively late sources that are still extant); while in the case of hanshi, there was a shift from onmyōji to physicians in its handling, and hanshi appears in most major onmyōdō manuals and compilations throughout the medieval period. However, this does not seem to have been the case with the birthing mat incantation. It is not attested in any onmyōdō texts, and there are no textual hints of sorts that suggest a more tortuous historical trajectory. This makes exceedingly clear that the source for this ritual is, once again, Ishinpō. Section six of scroll twenty-three, entitled "On the prohibitions for pregnant women as they sit on the straw [mat]," consists of another quote from Chan jing. It is, we are informed at the beginning of the passage, a formula to be uttered as one spreads the straw mat, i.e., the birthing bed. Of particular interest is the second part: a series of divinities, including the Queen Mother of the West, ${ }^{33}$ the Vermillion Bird, the Black Tortoise, immortals, and jade women are invoked to offer protection to the parturient and "prevent the many malicious spirits from approaching and touching [her]" (Ishinpō, vol. 5, pp. 1983-84). The formula ends with the set phrase "kyūkyu nyo ritsury $\bar{o}$ " ([do so] with most haste, in accordance with the ritsuryō codes), which we have already encountered in our discussion of shakuchimon. 
The birthing bed incantation is, in other words, a protective spell designed to plead with deities for protection. Once again, the figures that appear in the formula are not regular presences within any Japanese cultic tradition, and they would have most likely been recognized as hailing from the continent. It has been previously mentioned that childbirth constituted a particularly critical moment in a woman's life, as it was at the time not uncommon, even for women belonging to the highest ranks of society, to die during childbirth. The precariousness of this state was explained by positing a connection between the invisible world of malicious spirits and revengeful ghosts, and the bodily dimension of the parturient: childbirth exposed women to the attacks of those malicious creatures, most commonly referred to in sources as mono no ke or jake, which is why, especially in cases that involved royal consorts and, potentially, future sovereigns, countering those evil influences through the power of ritual was of paramount importance. Therefore, the setting in which the delivery was set to take place was crowded, multilayered, noisy, filled with a deluge of ritual agents, including Buddhist monks, onmyōji, and other miscellaneous figures, some from other government bureaus, some selected from outside of the institutional structure. Court physicians, often narrowly misinterpreted as agents of "medicine" or physical therapeutic modalities, partook in this process at various stages. At times, they fulfilled a role similar to that of onmyōji and monks, but in a fashion that was specific to their own tradition. The birthing bed incantation, rooted in continental ijutsu, ${ }^{34}$ was likewise devised to keep malicious entities away. Despite the unusual deities it invoked and its foreign origin, it responded to concerns that were strongly felt by the members of the Heian court.

\section{Conclusions}

Through an examination of three moments within the ritual process of pregnancy-the affixation of shakuchimon on the first day of the expected due month, the hemerological adjudications concerning hanshi, and the recitation of a protective incantation at the moment of setting up the birthing bed-I have attempted to emphasize aspects of the activity of court physicians that are generally neglected, both in Japanese and non-Japanese scholarship, namely their ritual and hemerological interventions. There are more episodes that could have been discussed in order to highlight the ritual dimension of the activities court physicians but for the sake of space, these had to be left out on this occasion: within the context of pregnancy, one sees physicians handling materia medica that is, however, not used for its medicinal properties, but rather as an apotropaic object that is then empowered through kaji 加持, a Buddhist rite; ${ }^{35}$ or handing apotropaic objects to the expecting woman in case of difficult delivery (Katsuura 2008, p. 19). Hemerological aspects are on display in scroll two of Ishinpō and in discussions on moxibustion, needles, and the position of jinshin 人神 (Ch. renshen), which are inner deities that were believed to inhabit the human body and circulate within it according various calendrical cycles. ${ }^{36}$

The purview of court physicians is too often simplistically equated, on the basis of morphological resemblances, with modern biomedicine. While some aspects of their therapeutic and preventive toolkit translate well, in that sense-e.g., the compounding of herbal or mineral medications - and some others are still represented in contemporary traditional Chinese medicine-primarily moxibustion and acupuncture, this paper makes clear that ijutsu is a complex tradition that also incorporates elements that too often get lost in translation. A common result of applying modern schemes to non-modern societies is the loss of nuance and a neglect of those aspects that do not fit well on the basis of one's chosen taxonomies. In this way, once ijutsu gets identified with "medicine" as opposed to "religion" - which in the period in question will be spotted somewhere else, most often in Buddhism or onmyōdō-talismans, hemerological elements, and incantations get relegated to the background. Ijutsu is not coextensive with any of the epistemological taxa we today utilize to organize the world around us. It is not "medicine" and it is not "religion" because it possesses elements that could be classified under both, and therefore, it would be more 
appropriate to say it is neither. It is a complex tradition with a long history, its own theorists, practitioners, canonical texts, and commentarial traditions.

One should also resist the temptation to see the history of ijutsu in Japan as a surrogate for the study of Daoism in Japan. It is well known that Daoist texts were never systematically transmitted to Japan, and that at no point were Daoist institutions established on the archipelago. There have been numerous attempts to rediscover the "Daoist" subtext in ancient Japanese history, ${ }^{37}$ but here I do not intend to venture into that fraught territory. While dated in some regards, Anne Seidel's classic study is still worth quoting:

"What many authors [ ... ] call Taoist practices at the Japanese court-divination, five-element sciences, time-keeping, calendar-making, astrology, prognostication, omen-lore, etc.-were Chinese traditions cultivated at every Chinese court. [ ... ] These traditions of what is properly called hemerology exerted a great deal of influence on Taoism; but they are a pan-Chinese branch of learning with its own chain of transmission distinct from Taoism. To a certain extent, the same is true for the Japanese assimilation of Chinese medicine. Since the Han period, the medical tradition was distinct from, although influenced by, Taoist longevity practices". (Seidel 1989, p. 301)

There are some important connections between ijutsu and Daoism on the continent, and both categories were to a certain extent fluid, as shown for instance by shifting categories in biographical essays of official histories. However, that whole argument is inconsequential once we examine the Japanese case. Practitioners of $i j u t s u$ at the Heijō and Heian courts were not Daoists in disguise. The institutional structure of the Bureau of Medication largely replicated that of the Tang, including the presence of specialists of jugon 呪禁 (incantation and interdiction), practitioners of incantations to interdict malicious $q i$ and to disentangle oneself from attacks, which are often discussed as evidence of direct Daoist influence in Japan. ${ }^{38}$ The texts collected in Ishinpō, a compendium of citations from hundreds of Chinese ijutsu scriptures, most likely include Daoist elements. For instance, we see numerous furoku (Ch.: fulu) — a form of talismanic writing often found in Daoismformulas with Daoist overtones, deities from the Daoist pantheon, and possibly texts that were originally produced in a Daoist context (but given the fragmentary nature of these sources, we are generally unable to make that call); but incidental Daoism is not, by any practical purpose, Daoism. What Yasuyori quotes in Ishinpō was mediated through ijutsu, as it had been previously treated or cited in ijutsu scriptures and compendia, and it is questionable whether he would have thought of it under any other label (unlike most texts of this kind in China, Ishinpō does not have an introductory essay, and therefore, any explicit authorial intent is inaccessible to the modern reader). It seems to me that this attempt to identify Daoist influences within the ritual and hemerological aspects of $i j u t s u$ is a way to, so to speak, put the blame somewhere else: where once there was "medicine," the encroachment of Daoism brought "religion". However, this attempt at rationalizing the presence of talismans, incantations, or hemerology within ijutsu overlooks elements one can observe already in some of the most ancient layers of the ijutsu canon, the Huangdi neijing 帝經 (Inner cannon of the Yellow Thearch). Just to give a couple of examples, Donald Harper has discussed the relationship between medicine and cosmological knowledge (on which divination and hemerology were based) in the Huangdi neijing (Harper 1999, pp. 91-110), and Maruyama Toshiaki has noted that oneiromancy and certain incantations were recognized within the framework of what he calls "Neijing medicine (Naikyō igaku 内 経医学)," despite their diminished role when compared, for example, to the manuscripts unearthed in Mawangdui (Maruyama 1988, pp. 241-54). ${ }^{39}$ It is likely that contacts with Daoism had the effect of reinforcing some of these aspects, but, at a basic level, what may look like epistemological contamination to us should perhaps be more appropriately interpreted as a cultural trait.

The three stages within the childbirth process examined in this paper show the direct influence of Ishinpo on the activities of court physicians. While periodization poses some issues that largely depend on the lack of records, we can say that by the twelfth century, 
these practices had become standard components of the ritual process of pregnancy and childbirth, but that their adoption should be more appropriately thought as older, in many cases, if not all, even preceding the compilation of Ishinpō. We have seen that shakuchimon was already mentioned in Rekirin, a tenth-century compilation on calendrics and hemerology, and that hanshi was being discussed at court already at the time of Shigeoka no Kawahito in the ninth century; concerning the incantation recited as the birthing mat was set up, I have been unable to find any traces of earlier adoption in Japanese sources. Given the limited materiality that these ritual actions involved-a paper talisman in one case, mats, ash, and some cowhide that would have by the end of the process been drenched in blood, amniotic fluid, and other bodily fluids in the otherarcheology is not a viable instrument to rediscover traces. However, it does provide some crucial hints once we turn our attention somewhere else.

On the occasion of preparatory excavations carried out around Nara-the old capital known as Heijō-kyō-at various sites over the years, among other structures and artifacts, jars were found at the bottom of carefully dug holes. In one of such findings, described by Mizuno Masayoshi, various items were found inside the jar: five wadōkaichin 和銅開珎 coins-the oldest coinage officially minted in Japan in 708-an ink block, a brush handle, and the pommel of what was probably a wooden small knife, preserved because it was made of rhino horn, a red piece of cloth, and some organic matter (Mizuno 1990, pp. 31-32). The objects found in jars excavated at other sites could vary to a certain extent-in another case, no coins were found, and the small knife was made of copper rather than wood (Nara kokuritsu bunkazai kenkyūjo 1995, pp. 25-26). However, in both cases, the function of these deliberately buried jars is clear: they are placenta disposal sites. Records in a handful of journals from the twelfth and thirteenth century describe how placenta was prepared after its expulsion: washed in pure water and saké first, then placed on top of the coins at the bottom of a jar with the other objects, which is a procedure that closely corresponds to the excavated placenta jar at the site described by Mizuno. This also brings us back to Ishinpō, since a section on how to dispose placenta, section fifteen in scroll twenty-three, closely mirrors these descriptions (Ishinpō, vol. 5, p. 2004). This account in Ishinpō is based once again on the Chan jing, but given the very early chronology of these excavations in the old capital of Nara, the source of those practices cannot, of course, be Ishinpo, and there is no indication that Chan jing had already reached Japan in the eighth century-its earliest occurrence is in the Nihonkoku kenzaisho mokuroku, which was compiled in the ninth century. Given the great similarities, it is possible that Chan jing was quietly brought to Japan by either immigrant monks from the Korean Peninsula or one of the embassies sent by the Japanese court to the Sui and Tang in the seventh or eighth century, or that both Chan jing and the source of the practice of placenta disposal attested in Nara are based on the same account.

A description found in Chōshūki 長秋記, the journal of the courtier Minamoto no Morotoki 師時 (1077-1136), is one of the earliest textual occurrences of the practice of burying the placenta. In an entry for the sixth day of the sixth month of the second year of Gen'ei (1119), Morotoki writes about the discussion concerning the disposal of the placenta after the safe birth of the baby who would later become Sutoku Tennō; both court physicians and onmyoji claimed, on the basis of their texts, that the placenta should be buried, but Kamo no Mitsuhira, also a member of the Bureau of Yin and Yang, intervened saying that on the basis of recent (近来) practice, the placenta should be tied to the rooftop of the residence (Chōshīki, vol. 1, p. 144). While what we see here is a transitional moment between the traditional practice of burying the placenta and a more recent way of handling it, which consisted of tying it to a high place, it is noteworthy that this practice appears in written sources only in the twelfth century, despite the fact that we can identify with certainty that those excavated jars are placenta disposal sites and that such practice dates back to the Nara period-the late eighth century. This is puzzling, but considering how all the ritual steps surrounding childbirth are first documented with a certain regularity starting from the twelfth and thirteenth century, we need to turn to the practice of male record keeping 
to find the culprit. Journals were written by men and transmitted within families through male lines because it was men who were employed in the court bureaucracy. I would dare to say it is crystal clear at this point that, on the basis of the textual crumbs we have followed for shakuchimon and hanshi, and on the basis of the practice of disposing of the placenta by burying it in jars, that male disinterest is to blame for the lack of certain records of these practices for centuries.

Another consideration to make, which runs through this entire paper and that is particularly germane to the topic of this special issue, is that the transmission of $i j u t s u$ to Japan is, in its entirety, a history of Chinese influence on Japanese culture and society. Ishinpō, usually designated the oldest extant medical text in Japan, is essentially a compilation of scriptures from the Six Dynasties, Sui and Tang China, reworked through Japanese eyes but still peculiarly Chinese. In this sense, it is not an overstatement to say that any form of social or intellectual influence exerted by Ishinpō is an expression of certain aspects of Chinese literary culture and of those technical groups produced it. This is particularly conspicuous in some lists, such as those we have seen in the texts of the incantations for shakuchimon and the setting up of the birthing bed, to the point that they pose difficulties of interpretation, alien as they are to the rest of the ritual landscape of the time. While hanshi/fanzhi hemerology has extremely old roots in China, its presence in Japan is only attested in an ijutsu context. Significantly, it was not part of the standard annotations that members of the Bureau of Yin and Yang made on guchüreki, the annotated calendars that court aristocrats used as calendars, hemerological guides for their daily lives, and on which they penned their journals.

The transmission of these aspects of continental culture to the Japanese archipelago took place in a piecemeal fashion-not unlike other traditions-but this process is largely invisible to us. Since the earliest historical records, there is evidence that Buddhist monksimmigrant monks from the Korean peninsula, in particular-functioned as conduits not merely for those aspects that we would readily identify as Buddhist but also for other facets of continental culture, including material culture, divination, calendrics, astrology, and other non-Buddhist ritual regimes. Ijutsu was also part of these dynamics, as revealed, for instance, by the case of the monk Keishun 恵俊, who was a specialist of ijutsu who was laicized through an imperial edict in the year 700 and eventually given the lay name Kichita no Muraji Yoroshi so that he could serve in the Bureau of Medications. ${ }^{40}$ There are, in any case, many aspects that are not clear in this process of transmission with regard to the ritual and hemerological aspects of $i j u t s u$ discussed in this paper; on the basis of what we have seen above, it seems to be the case that, possibly at a stage when Sui/Tang-influenced ijutsu was not yet conceived as an organic whole, shakuchimon and hanshi were handled by onmyōji, as the cases of Kamo no Yasunori and his Rekirin (in which, as the reader may remember, there was also a scroll or section on the Chan jing), and, about a century before him, Shigeoka no Kawahito show. In the entry on hanshi in the Onmyō kikkyō shō, there is an explicit allusion to a shift in competence, from onmyōji to physicians, which is a process that seems to be buttressed by the scant sources we have at our disposal. More specifically, the compiler of the Onmyō kikkyō shō locates this passing of the baton during the lifetime of Yoshihira, an onmyojji who was active in the late tenth and early eleventh century, eventually passing away in 1026. We know that Yoshihira died only about two weeks after the passage in Sakeiki in which hanshi was discussed, which is a fact that indicates that during his lifetime, adjudications on hanshi were still clearly the responsibility of onmyōji. However, if we take the note in Onmyō kikkyō shō as an approximate indication, that shift can be thought of as a consequence of the compilation and use at court of Ishinpō. The text was presented to the throne in 984, and while there were earlier compendia of ijutsu, such as the Daidō ruijuhō 大同類聚方 (Classified recipes from the Daidō era), they seem to have exerted little influence and to have disappeared quickly. Ishinpō, on the other hand, became the benchmark for the therapeutic activities of physicians for the following centuries; it is plausible to think that once a new generation of physicians had become familiar with the voluminous texts, the first systematic description of continental ijutsu in all its aspects-the 
responsibility over hanshi hemerology, land-leasing talismans, and other pregnancy-related ritual moments that were, up to that moment, within the purview of onmyōji-was handed over to them.

Although plausible, this is naturally only a conjecture, but the historically close (and, possibly, contested) connection between onmyōji and physicians in many domains that were influenced by Chinese ritual regimes or depended on Chinese textual traditions has not been properly investigated, and it remains a crucial topic in ancient and medieval Japan history that requires further attention.

Funding: This research was funded by Japan Society for the Promotion of Science, grant number 20F20782.

Institutional Review Board Statement: Not applicable.

Informed Consent Statement: Not applicable.

Conflicts of Interest: The author declares no conflict of interest.

\author{
Abbreviations \\ ZGR: Zoku gunsho ruiju 続群書類従. 37 volumes. Edited by Hanawa Hokinoichi and Ōta Tōshirō. \\ Tokyo: Zoku gunsho ruiju kankōkai. 1957-1959. \\ ZST: Zōho shiryō taisei 増補 史料大成. Kyoto: Rinsen shoten
}

\title{
Notes
}

1 Tennō 天皇is the title of Japanese sovereigns. Today, it is most commonly translated as "emperor," but some have questioned the applicabilty of that translation to premodern Japan, for example on the basis of its gendered nature (in premodern Japan, there were female tennō) and the fact that it seems to demarcate a polity founded on conquest; see for instance (Piggott 1997). It is sometimes translated as "heavenly sovereign" or "heavenly thearch," but I prefer to leave it untranslated in this paper.

2 The modern term for medicine is igaku 医学, and numerous Japanese scholars employ it to discuss the purview of court physicians; see for instance Hattori $(1955,1964)$, two classic studies in the medical history of Japan. Some scholars prefer to employ the neologisms “Chinese medicine" (Chūgoku igaku 中国医学) or "traditional Chinese medicine" (Chūgoku dentōigaku 中国伝統医 学); or the modern designation for Japanese-style traditional Chinese medicine, kanpō (lit., "Chinese recipes"). See for instance Kosoto (2014), whose title can be translated into English as "History of kanpō: the traditional medicine of China and Japan". I should also note that while the term "medicine" is sometimes used by historians of East Asian medicine in an inclusive fashion, designating therapeutic modalities at large, in Japanese the term igaku is as a rule used in a narrower sense, close to modern biomedicine; on the other hand, inclusive terms are, for example, iryō 医療and chiryo 治療. In other words, the use of the term igaku in Japanese scholarship concerning the activities of court physicians involving decoctions, needling and moxibustion often reveals the authors' attitude toward the records in question. While the hemerological, mantic, and ritual dimensions of East Asian "medicine" have long been recognized by historians, I should emphasize that in this paper I am not primarily concerned with specialized, prescriptive texts per se, but rather with the correspondence between descriptions found in such texts (e.g.,

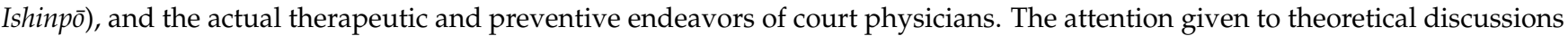
and the neglect reserved for instances of their actual use may suggest that those aspects only existed on paper. This study, while focusing only on pregnancy and childbirth, makes clear that is not the case.

3 Tanba no Yasuyori's dates are based on the colophon of scroll 30 of the so-called Engyo manuscripts of Ishinpō, where his death is dated Chōtoku 1 (912)/4/19, and his age at the moment of death is given as 84 (according to the traditional East Asian reckoning). See (Sugitatsu 1991, pp. 215-16).

4 For an English translation of scrolls 1 and 2, see Hsia et al. (1986a); for a modern Japanese translation of scroll 2, see for example (Nihon koigaku shiryō sentā 1975); and Kamata et al. (1982) for an annotated Classical Japanese rendition. Scroll 28 was until the war period considered unsuitable for publication and scholarly attention-the earliest printed scholarly edition of Ishinp $\bar{o}$, published in 1906 by renowned physicians and medical historians (including Fujikawa Yū), did not include scroll 28. Starting from the postwar period, there has been an explosion of (not always academically sound) interest in said scroll, which has been, as far as I have been able to ascertain, published in at least five annotated or modern language editions. See, for instance, Umayahara et al. (1982), which includes commentary by the famous medical historian Ishihara Akira. Scroll 28 has also been translated into English on at least two occasions: see Hsia et al. (1986b, pp. 149-241) and Ishihara and Levy (1970), the latter under the splashy title of The Tao of Sex. Wile (1992) also includes a study and partial translation of scroll 28.

5 The text I use is the one collected in the photographic reproduction of the Nakaraike manuscript of Ishinpō published by Oriento shuppansha, volume 5. Scroll 23 exists in no other ancient recension of Ishinpō other than the Nakaraike manuscripts; it does not survive, for instance, in the so-called Ninnaji manuscripts, today held at Ninnaji (three complete scrolls and two incomplete) and 
Sonkeikaku bunko (first half of scroll 27). An annotated edition, which however needs to be used with great care, can be found in Maki (1998). My interpretation of passages often differs from that found in this edition. Jen-der Lee briefly discusses some sections of scroll 23; see (Lee 2005, 2012).

6 I use $i j u t s u$ ( $i$ techniques) rather than $i$ to avoid ambiguities, given the monosyllabic nature of the latter. In any case, the term ijutsu is widely attested in sources from all periods of Japanese history. Another word with similar meaning is $i d \bar{o}$ 医道 (way of $i$ ).

7 On the early history of the transmission of continental culture to Japan, see for instance Hashimoto (1991) and Shinkawa (1994, pp. 199-220). I should note here that whereas similar skepticism also applies to the taxon of "religion," in this paper, I focus on what might be labeled as the "religious" aspects of ijutsu because they are underrepresented in the scholarship on court physicians and their activities. I will return to this issue in the conclusion.

8 While for the period in question relatively little is known concerning how childbirth was dealt with outside of the court and its

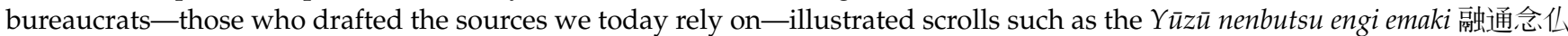
縁起絵巻 (Illustrated legends of Yūzū nenbutsu) allow us to get a glimpse of life beyond the court. In the ninth section of the second scroll, we see a parturition scene: in a hut facing a busy crossroad, a woman is standing, supported by two women, one of whom is embracing her from the back. Facing them, a monk is writing something, likely carrying out rituals for safe childbirth. The hut is entirely open onto the crossroad, which gives this parturition scene a markedly public dimension. On the basis of this and other images, one can say that childbirth as described in this paper was most likely an exclusive trait of the upper echelons of court bureaucracy. On the $Y \bar{u} z \bar{u}$ nenbutsu engi emaki parturition scene and other depictions in visual sources, see Hotate (1986).

9 In Japanese, see Morimoto (2002); in English, see Gunji (2018).

10 For more general studies, other than those mentioned above (see previous note), on these topics see for example, in English, Andreeva (2014) and Tonomura (2007); in Japanese, Nakamura (1968, pp. 10-79), Shinmura (1996), and Katsuura (2008). Especially, this latter article has shaped my understanding of some of the issues I discuss in this paper, although my analysis is narrower and more focused. I should also notice that while one of Katsuura's aims is to identify Daoist influences in the ritual practices of court physicians, I explicitly reject this approach. I will briefly return to this issue in the conclusion.

11 I use the edition of Osan buruiki based on the Fushimi no Miya manuscript now held at the Archives and Mausolea Department (Shoryōbu 書陵部) of the Imperial Household Agency (Kunaichō 宮内庁). This manuscript also incorporates the Osan buruiki collected in volume 32-2 of Zoku gunsho ruiju, which are sometimes used by scholars despite some philological issues, and it is believed to have been copied in the thirteenth century.

12 In this paper, onmyōdō ("the way of yin and yang") strictly refers to the ideas and activities of the Bureau of Yin and Yang (Onmyōryō 陰陽葟) and its members, which were generically called onmyōji (masters of yin and yang) in most sources—despite the fact that, narrowly speaking, onmyōji was only one of many positions within the bureau. At the time of its foundation in the eighth century, the activities of officials within the bureau were divided into four branches: (1) the department of yin and yang (from which the bureau as a whole took its name), responsible for divination through the interpretation of patterns of yin and yang; (2) the department of calendrics, in charge of the production of the annual calendar and calendrical predictions; (3) the tenmon department, which roughly corresponds to a mix of modern day astronomy and astrology, since its members were in charge of the observation of the sky in order to identify and interpret possible anomalies, and report them to the court; and (4) time-keeping. These four branches had all originated in China. Later on, starting from the late ninth century, onmyōji also started to be actively engaged in rituals, public and private, meant to resolve bad omens, prevent disasters, and so on. For general introductions to onmyōdō, see Suzuki (2002) and Yamashita (2010).

13 As it is common scholarly practice among historians of premodern East Asia, terms such as China or Japan are used heuristically. They imperfectly map onto the corresponding modern nation-states.

14 The ideas and practices discussed below first emerged on the continent but were, as previously mentioned, brought to the Japanese archipelago by practitioners under various banners-Buddhist monks, physicians, experts of other sorts—and eventually recorded in Ishinpō by Yasuyori, and in other texts that will appear below. Curiously, some of them are barely mentioned in extant Chinese sources to the extent that, in order to build a narrative on childbirth in early medieval China, Jen-per Lee (2005) has to copiously rely on Ishinpō.

15 In his journal, Kanezane's standard designation for his consort is “nyōbō 女房," which is a generic term encompassing a semantic area ranging from adult woman, court lady, to one's wife. In this period, women were not known under their personal names but through a relational designation (the daughter of, the wife of); Studies have identified Kanezane's consort as Fujiwara no Kenshi 兼子, the daughter of the court aristocrat Fujiwara no Sueyuki 季行 (1114-1162). See Miyazaki (2013) and Taga (1974, pp. 450-58). Gyokuyō, entry for Shōan 3/8/17 (vol. 2, pp. 264-65). Kanezane defines it "propitious" as he had used it as a birthing place previously and that pregnancy had concluded successfully. This shows that also on the occasion of Kenshi's previous pregnancy in 1167, Kanezane had temporarily leased said residence.

17 Sankaiki, entry for Jishō 2/10/1 (vol. 2, p. 145); also in Osan buruiki (vol. 2, p. 63). Interestingly, while Tokushi was expected to give birth in the tenth month-which is why the shakuchimon ritual was held on the first day of that month-she would eventually deliver her baby only on the twelfth day of the eleventh month. Despite this, the land-leasing talisman does not seem to have been renewed on the first day of the eleventh month, and we see no mention of it in that day's entry. 
Consorts of retired tennō were in this period customarily given honorific names ending in mon'in. These soubriquets were based on the names of the gates (mon) granting access to the court, to the tennō's residence, and to other buildings within the court precincts, with the addition of in at the end. For instance, Shōkunmon (Shōkun gate) was located at the northeastern side of the Administration Halls (Chōdōin 朝堂院) complex, while Kōgimon (Kōgi gate) was located at the northwestern side of the same complex.

19 There is a large amount of scholarship on this formula, not only in Japan but also in China and Korea; see for example Wada (1995) and Yamazato (1999).

20 For a recent and useful introduction to the complex topic of kegare (defilement), see Kataoka (2013, pp. 8-85).

21 Onmyō kikkyō shō (p. 230). I have first found mention of this in Katsuura (2008, p. 14).

22 Shirai (2013) has shown that the custom of utilizing shakuchimon on the occasion of childbirth also spread to the Korean Peninsula and is documented from at least the fifteenth to the nineteenth century. A Korean text today held at the Kyōu Shooku archive in Osaka, entitled Sansilcheong chonggyu産室庁総規, interestingly mentions a printing matrix for shakuchimon (Kr: chajimun) instead of hand-written talismans as at the Heian court. Shirai also observes that in Joseon Korea, there was a division of labor between those tasked with chanting the land-leasing formula—as in Japan, court physicians (in Joseon called uigwan医官)—and those tasked with picking a propitious date, those tasked with picking a propitious direction, and those tasked with adjudicating on a place to bury the placenta, which were all functions that in Japan were fulfilled by onmyoji. Despite a scarcity of sources that makes the history of the early Korean Peninsula largely inaccessible, it is clear that shakuchimon and other ritual practices associated with the activities of court physicians within the context of pregnancy and childbirth possess a regional dimension and should also be studied and located within that context. See also supra, note 17.

Since hanshi is first and foremost a hemerological notion, it does not seem to possess a directional component per se. However, it is possible that since earthly branches are also used as directional markers, a connection was made via this aspect. I thank one of the anonymous reviewers for this observation.

25 The Shiryō Taisei edition of Sankaiki (vol. 2, p. 164) here reads “基親問日、遊所在” (punctuation was added by the Shiryō Taisei editors) but, judging from the context, it seems quite likely that the passage should read “基親問日遊所在”. “日” is usually used to introduce reported speech; the first four characters of first passage can be thus translated "Motochika asked saying," but the rest of the sentence becomes difficult to parse. On the basis of my suggested amendment (日 instead of 日), the sentence reads, "Chikamoto asked about the location of Nichiyū".

26 Doyo 土用 is the period of eighteen days that precedes the first day of each season according to the traditional East Asian lunisolar calendar. More specifically, as in this case, it indicates the first day of each eighteen-day period, when construction works and other activities were considered taboo.

Interestingly, the mention that silk should be spread on top of the ashes is followed by an interlinear note that reads. "Or the silk should not be spread". This suggests the influence of later developments. In Shōkunmon'in osan guki from 1303, in an entry for Kengen 2/5/9, it is written that this spread-which here consisted of two layers, one of hemp and one of silk-was usually applied, but that in this case, this passage was skipped (然而今度略之); an interlinear note adds that starting from the Kangen era (1243-1247), it had become common to omit this passage. (Kinhira kōki, vol. 3, p. 105) Once again, the two bekki written by Saionji Kinihira allow us to rediscover a sense of diachrony within the practices under examination.

On directional deities, including Ten'itsu and Nichiyū, see Bernard Frank's pioneering study from Frank (1958). Research on Nichiyū has not progressed much over the last decades.

29 I by no means intend to suggest that hanshi originated within ijutsu. "Reverse branch" hemerology is indeed already attested in the so-called daybooks (rishu 日書) excavated from various tombs in Hubei, Henan, and other Chinese provinces. Some of these daybooks-almanacs containing hemerological information meant to provide guidance for one's daily activities-date back to the Qin (3rd century-207 BCE) and Han (206 BCE-220 CE) periods. It is worth noticing that at this point, there were multiple systems to calculate fanzhi (Jp. hanshi) in use, as one can see by comparing the daybooks excavated at Kongjiapo and Shuihudi, both in Hubei province; and that "reverse branch" hemerology at this time only consisted of fanzhi days. The hanshi day scheme found in Ishinpō closely resembles that presented in one of the Shuihudi daybooks, but the source for the hanshi month system and its connection to childbirth is, at this point, something I have not been able to ascertain. On daybooks and various issues of divination and hemerology in ancient China, see, in Japanese, (Kudō 2011); more specifically on fanzhi hemerology in daybooks, (Mori 2009); on daybooks in English, see (Harper and Kalinowski 2017), and, more specifically on fanzhi, the piece by Christopher Cullen in the same book (Cullen 2017).

The only difference between the two systems is that hanshi based on the age of the pregnant woman in Ishinpō has only one associated hanshi month, while Yoshihira gives two in his report. The tenth month applies in both cases.

Sankaiki, entry for Jishō 2/11/12 (vol. 2, p. 169).

32 A short biography of Kawahito can be found in Nihon sandai jitsuroku 日本三代実録 (Veritable Records of three generations [of rulers] of Japan), the sixth and last official history completed in 901, in the entry for the day of his death, namely Jogan 16 (874)/5/27 (Nihon sandai jitsuroku, p. 342-43). In Sakeiki, entry for Chōgen 1 (1028)/4/5, his divination board is defined "object endowed with numinous powers" (p. 216). 
For a study of the Queen Mother of the West in Japan (albeit in an earlier period of Japanese history), see Como (2009, pp. 84-108). Other than in the no longer extant Chan jing, which is quoted in Ishinpō, I have found a similar formula in scroll seventy-six of the Taiping shenghai fang 太平聖恵方 (Sagely and benevolent recipes of the Taiping [era]), a Song period ijutsu compendium compiled in 978-992, and, later on, in the Taiping huiming hejijufang 太平惠民和劑局方 (Recipes to benefit the people from the Pharmaceutical Bureau of the Taiping [era]), which was compiled in 1107-1110. However, these texts do not provide their sources, and at this time, I have been unable to further pursue the genealogy of the birthing bed incantation within continental $i j u t s u$.

This is the case of senshōshi 仙沼子, which are presented by physicians to the pregnant woman on the occasion of a ceremony known as "putting on the [pregnancy] sash" (chakutai no gi 着帯儀), which usually took place in the fifth month of pregnancy. These seeds were not used in medicinal preparations, but they were sewed into the pregnancy sash that was later empowered by a Buddhist monk. In Japanese, see (Katsuura 2008, pp. 9-10); in English, (Andreeva 2020).

On jinshin, see for instance Shinmura (1985, pp. 377-78); Minobe et al. (2006, pp. 20-21); and Tsujimoto (2010, pp. 23-24); about inner deities within Daoism, see Pregadio (2008, pp. 80-84).

37 For some recent approaches to this issue, see the essays collected in Richey (2015).

38 On jugon, see for example (Shimode 1972, 1997). In any case, on the basis of commentaries on the ritsuryō codes in which a description of jugonshi (masters of jugon) appear, jugon seems to closely resemble techniques found in Baopuzi (Master who embraces simplicity; completed ca. 317-318), the main work of Ge Hong (283-343), a philosopher and alchemist active in the Jin kingdom who should be more appropriately seen as a representative of the fangshi 方士 (master of methods) tradition, rather than as a Daoist.

39 I should also note that Maruyama attributes to the influence of Daoism the increase of these "non-medical" elements in Tang sources such as the Waitai miyaofang and the Qianjinfang (Maruyama 1988, p. 245).

40 On Keishun/Kichi no Yoroshi/Kichita no Muraji Yoroshi, see (Hashimoto 1991); for his side as a man of letters, see (Sakuma 1983, pp. 226-41).

\section{References}

\section{Primary Sources}

Chōshūki 長秋記. 2vols. ZST 16-17.

Gyokuyō 玉葉. 13 vols. Kujōke-bon Gyokuyō 九条家本玉葉. Zushoryō sōkan 圖書寮趣刊. Kunaicho shoryōbu 宮内庁書陵部, $1994-2013$. Hyōhanki 兵範記. 5 vols. ZST 18-22.

Ishinpo 医心方. 6 vols. Nakaraike-bon Ishinpō 半井家本医心方. Osaka: Oriento shuppansha オリエント出版社, 1991.

Kinhira kōki 公衡公記. 4 vols. Shiryō sanshū kokiroku hen 史料纂集 古記録編3, 7, 41, 58. Tokyo: Zoku Gunsho Ruiju Kanseikai, 1968-1979

Kōgū osan tōjitsu shidai 后宮御産当日次第. ZGR 33-2.

Nihonkoku kenzaisho mokuroku 日本国見在書目録. ZGR 30-2.

Nihon sandai jitsuroku 日本三代實錄. Shintei zōho kokushi taikei 新訂増補国史体系4. Edited by Kuroita Katsumi and Kokushi Taikei Henshūkai. Tokyo: Yoshikawa kōbunkan. 2000 [latest edition].

Onmyō kikkyō shō 陰陽吉凶抄. In Takada and Takuma 2001, pp. 188-231.

Osan buruiki 御産部類記. 2 vols. Zushoryō sōkan 圖書寮叢刊. Kunaicho shoryōbu 宮内庁書陵部, 1981-1982.

Qianjinfang 千金方. In Xindiao Sun zhenren Qianjinfang: Song han; Zhenben Qianjinfang: guchaoben 新雕孫真人千金方: 朱版; 真本千金方: 古鈔本. Osaka: Oriento shuppansha オリエント出版社, 1989.

Sakeiki 左経記. ZST 6.

Sanchōki 三長記. ZST 31.

Sankaiki 山槐記. 3 vols. ZST 26-28.

Shōyūki 小右記. 11 vols. Dai Nihon kiroku 大日本記録. Tokyo: Iwanami shoten, 1959-1986.

Utsuho monogatari 宇津保物語. 3 vols. Shinpen Nihon koten bungaku zenshū 新編日本古典文学全集14-16. Tokyo: Shōgakukan, 1999-2002.

Waitai miyaofang 外台秘要方. 2 vols. Waitai miyaofang: Song ban 外台秘要方: 宋版. Osaka: Oriento shuppansha オリエント出版社, 1981.

\section{Secondary Sources}

Andreeva, Anna. 2014. Childbirth in Aristocratic Households of Heian Japan. Dynamis 34: 357-76. [CrossRef] [PubMed]

Andreeva, Anna. 2020. Empowering the pregnancy sash in medieval Japan. In Buddhist Healing in Medieval China and Japan. Edited by Salguero C. Pierce and Andrew Macomber. Honolulu: University of Hawaii Press.

Como, Michael. 2009. Weaving and Binding: Immigrant Gods and Female Immortals in Ancient Japan. Honolulu: University of Hawai'i Press.

Cullen, Christopher. 2017. Calendars and calendar making in Qin and Han times. In Books of Fate and Popular Culture in Early China. Leiden: Brill.

Frank, Bernard. 1958. Kata-imi Et Kata-Tagae: Étude Sur Les Interdits De Direction À L'époque Heian. Paris: Presses Universitaires De France. 
Gunji, Naoko. 2018. Taira no Tokushi's birth of Emperor Antoku. In Women, Rites, and Ritual Objects in Premodern Japan. Edited by Karen Gerhart. Leiden: Brill.

Harper, Donald. 1999. Physicians and diviners: The relation of divination to the medicine of the Huangdi neijing (Inner canon of the Yellow Thearch). In Divination Et Rationalité En Chine Ancienne. Edited by Karine Chemla, Donald J. Harper and Marc Kalinowski. Saint-Denis: Presses Universitaires de Vincennes.

Harper, Donald, and Marc Kalinowski. 2017. Books of Fate and Popular Culture in Early China: The Daybook Manuscripts of the Warring States, Qin, and Han. Leiden: Brill.

Hashimoto, Masayoshi 橋本政良. 1991. Chokumei genzoku to hōgi kanryō no keisei 勅命還俗と方技官僚の形成. In Onmyōdō Sōsho 1: Kodai 陰陽道叢書 1 古代. Tokyo: Meicho Shuppan.

Hattori, Toshirō 服部敏良. 1955. Heian jidai igaku no kenkyū 平安時代医学の研究. Kyoto: Kuwana Bunseidō.

Hattori, Toshirō 服部敏良. 1964. Kamakura jidai igaku shi no kenkyu 鎌倉時代医学史の研究. Tokyo: Yoshikawa Kōbunkan.

Hotate, Michihisa 保立道久. 1986. Shussan no jōkei 出産の情景. In Chūsei no ai to jūzoku: Emaki no naka no nikutai 中世の愛と従属：絵 巻の中の肉体. Tokyo: Heibonsha.

Hsia, Email C. H., Robert H. Geertsma, and Ilza Veith, eds. 1986a. The Essentials of Medicine in Ancient China and Japan: Yasuyori Tamba's Ishimpo. Part One: Books 1 and 2. Leiden: E.J. Brill.

Hsia, Email C. H., Robert H. Geertsma, and Ilza Veith, eds. 1986b. The Essentials of Medicine in Ancient China and Japan: Yasuyori Tamba's Ishimpo. Part Two: Books 26, 27 and 28. Leiden: E.J. Brill.

Ishihara, Akira, and Howard S. Levy. 1970. The Tao of Sex: An Annotated Translation of the Twenty-Eighth Section of the Essence of Medical Prescriptions (Ishimpō). New York: Harper \& Row.

Kamata, Tadashi 鎌田正, Takashima Bun'ichi 高島文一, and Nakamura Shun'ya 中村俊也, eds. 1982. Ishinpō. Maki dai 2: Shinkyū 醫心 方. 卷第二, 銊炎. Tokyo: Shibundō.

Kataoka, Kōhei 片岡耕平. 2013. Kegare to shinkoku no Chūsei 穢れと神国の中世. Tokyo: Kōdansha.

Katsuura, Noriko 勝浦令子. 2008. Kodai, Chūsei Zenki Shussan Girei ni Okeru ishi, Isho no Yakuwari 古代・中世前期出産儀礼におけ る医師・医書の役割. Kokuritsu Minzoku Hakubutsukan Kenkyū Hōkoku 国立民族博物館研究報告 141: 7-39.

Kosoto, Hiroshi 小曽戸洋. 2014. Kanpō no rekishi: Chūgoku, Nihon no dentō igaku 漢方の歴史: 中国・日本の伝統医学. Tokyo: Taishūkan Shoten.

Kudō, Motoo 工藤元男. 2011. Uranai to chūgoku kodai no shakai: Hakkutsu sareta kobunken ga kataru 占いと中国古代の社会: 発掘された 古文献が語る. Tokyo: Tōhō Shoten.

Lee, Jen-der. 2005. Childbirth in Early Imperial China. Nan Nü 7: 216-86. [CrossRef]

Lee, Jen-der. 2012. Ishinpo and Its Excerpts from Chanjing: A Japanese Medical Text as a Source for Chinese Women's History. In Overt and Covert Treasures: Essays on the Sources for Chinese Women's History. Edited by Clara Wing-Chung Ho. Hong Kong: The Chinese University of Hong Kong Press.

Maki, Sachiko 梖佐知子, ed. 1998. Ishinpō. maki 23: Sanka chiryō, girei hen 医心方. 卷二十三, 産科治潦・儀礼篇. Tokyo: Chikuma Shobō.

Maruyama, Toshiaki 丸山敏秋. 1988. Kōtei naikyō to Chūgoku kodai igaku: Sono keisei to shisōteki haikei oyobi tokushitsu 黄帝内経と中国古 代医学: その形成と思想的背景および特質. Tōkyō: Tōkyō Bijutsu.

Minobe, Shigekatsu 美濃部重克, Nakane Chie 中根千絵, Ono Yūko 小野裕子, and Tsujimoto Hiroshige 辻本裕成. 2006. Kaisetsu 解説. In Idanshō 医談抄. Edited by Minobe Shigekatsu. Tokyo: Miyai Shoten.

Miyazaki, Yasumitsu 宮崎康充. 2013. Fujiwara no Kanezane shitsu 'Kenshi' ni tsuite 藤原兼実室「兼子」について. In Gyokuyōo yomu: Kujō Kanezane to sono sekai 玉葉を読む：九条兼実とその世界. Edited by Obara Hitoshi. Tokyo: Bensei Shuppan.

Mizuno, Masayoshi 水野正好. 1990. Dōkyō to majinahi 道教とまじなひ. Bunkazai gakuhō 文化財学報 8: 31-43.

Mori, Kazu 森和. 2009. Rinichi to hanshihi kara miru 'nissho' no keishō kankei 離日と反支日からみる「日書」の継承関係. In Higashi Ajia kodai shutsudo moji shiryō no kenkyū 東アジア古代出土文字資料の研究. Edited by Kudō Motoo 工藤元男 and Yi Sŏng-si 李成 市. Tokyo: Yūzankaku.

Morimoto, Sensuke 森本仙介. 2002. Tennō no shussan kūkan 天皇の出産空間. In Tennō to ōken o kangeru: 8 Kosumorojii to shintai 天皇と 王権を考える：8コスモロジーと身体. Edited by Amino Yoshihiko 網野善彦. Tokyo: Iwanami Shoten.

Nakamura, Yoshio 中村義雄. 1968. Ōchō no füzoku to bungaku 王朝の風俗と文学. Tokyo: Hanawa Shobō.

Nara kokuritsu bunkazai kenkyūjo 奈良国立文化財研究所, ed. 1995. Heijō-kyō sakyō sanjō ichibō jūshitsubo hakkutsu chōsa hōkoku 平城京 左京三条一坊十四坪発掘調査報告. Nara: Nara Kokuritsu Bunkazai Kenkyūjo.

Nihon koigaku shiryō sentā 日本古医学資料センター, ed. 1975. Ishinpō. Shinkyū hen: Gendaiyaku tsuketari Ansei-ban genbun 医心方. 鍼 负篇: 現代訳付安政版原文. Tokyo: Shuppan Kagaku Sōgō Kenkyūjo.

Piggott, Joan R. 1997. The Emergence of Japanese Kingship. Stanford: Stanford University Press.

Pregadio, Fabrizio. 2008. Inner deities. In Encyclopedia of Taoism. London: Routledge.

Richey, Jeffrey L. 2015. Daoism in Japan: Chinese Traditions and Their Influence on Japanese Religious Culture. London: Routledge.

Seidel, Anna. 1989. Chronicle of Taoist Studies in the West 1950-1990. Cahiers d'Extrême-Asie 5: 223-347.

Sakuma, Ryū 佐久間龍. 1983. Nihon kodai sōden no kenkyū 日本古代僧伝の研究. Tokyo: Yoshikawa Kōbunkan.

Salguero, C. Pierce. 2018. Healing and/or salvation? The relationship between religion and medicine in medieval Chinese Buddhism. In Working Paper Series of the HCAS “Multiple Secularities: Beyond the West, beyond Modernities". Leipzig: Leipzig University.

Shimode, Sekiyo 下出積與. 1972. Ritsuryō taisei to dōshihō 律令体制と道士法. In Nihon kodai no jingi to dōkyō 日本古代神祇と道教. Tokyo: Yoshikawa Kōbunkan. 
Shimode, Sekiyo 下出積與. 1997. Dōkyō to ritsuryō 道教と律令. In Nihon kodai no Dōkyō, On'yōdo to Jingi 日本古代の道教・陰陽道・神 祇. Tokyo: Yoshikawa Kōbunkan.

Shinkawa, Tokio 新川登亀男. 1994. Nihon kodai bunkashi no kōsō: Sofu ōda denshōo yomu. 日本古代文化史の構想：祖父欧打伝承を読む. Tokyo: Meicho Kankōkai.

Shinmura, Taku 新村拓. 1985. Kiryō no sekai 祈療の世界. In Nihon iryō shakaishi no kenkyū 日本医療社会史の研究. Tōkyō: Hōsei Daigaku Shuppankyoku.

Shinmura, Taku 新村拓. 1996. Shussan to seishokukan no rekishi 出産と生殖観の歴史. Tokyo: Hōsei Daigaku Shuppankyoku.

Shirai, Jun 白井順. 2013. Anzan ni wa chi o karu: Higashi Ajia ni okeru shussan jujutsu 安産には地を借る: 東アジアにおける出産 呪術. In Jutsu no shisō: I, chōsei, ju, kōrei, fūsui 術の思想: 医 ·長生・呪・交霊・風水. Edited by Miura Kunio 三浦國雄. Tokyo: Fūkyōsha.

Sugitatsu Yoshikazu 杉立義一. 1991. Ishinpō No Denrai 医心方の伝来. Kyoto: Shibunkaku Shuppan.

Suzuki, Ikkei 鈴木一馨. 2002. On'yōdō: Jujutsu to Kijin No Sekai 陰陽道：呪術と鬼神の世界. Tokyo: Kōdansha.

Taga, Munehaya 多賀宗隼. 1974. Kanezane to sono shūi 兼実とその周囲. In Gyokuyō sakuin 玉葉索引. Tokyo: Yoshikawa Kōbunkan.

Takada, Yoshihito, and Naoki Takuma, eds. 2001. On'yōdō kankei shiryō 陰陽道関係史料. Tokyo: Kyūko Shoin.

Tonomura, Hitomi. 2007. Birth-Giving, and Avoidance Taboo: Women's Body versus the Historiography of 'Ubuya. Japan Review 19: $3-45$.

Tsujimoto, Hiroshige 辻本裕成. 2010. Kiroku no naka no ishitachi 記録の中の医師達. Nanzan daigaku Nihon bunka gakka ronshū 10: 15-35.

Umayahara, Shigeo 馬屋原成男, Ishihara Akira 石原明, Takada Shōjirō 高田正二郎, and Iida Yoshirō 飯田吉郎, eds. 1982. Ishinpō. Maki dai 28: Bōnai 醫心方. 卷第廿八, 房内. Tokyo: Shibundō.

Wada, Atsumu 和田萃. 1995. Jufu mokkan no keifu 呪符木簡の系譜. In Nihon kodai no girei to saishi, shinkō chū 日本古代の儀礼と祭 郝 ·信仰 中. Tokyo: Hanawa Shobō.

Wile, Douglas. 1992. Art of the Bedchamber: The Chinese Sexual Yoga Classics: Including Women's Solo Meditation Texts. Albany: State University of New York Press.

Yamashita, Katsuaki 山下克明. 2010. Onmyōdō no hakken 陰陽道の発見. Tokyo: NHK Books.

Yamazato, Jun'ichi 山里純一. 1999. ‘Kyūkyū nyo ritsuryō' kō 「急急如律令」考. Nihon Tōyō Bunka Ronshū 日本東洋文化論集 5: 1-18.

Zheng, Jinsheng, Nalini Kirk, Paul D. Buell, and Paul U. Unschuld, eds. 2018. Ben Cao Gang mu Dictionary. Volume 3: Persons and Literary Sources. Oakland: University of California Press. 